\title{
Genetic analysis of Escherichia coli 09 rfb: identification and DNA sequence of phosphomannomutase and GDP-mannose pyrophosphorylase genes
}

Tsuyoshi Sugiyama, ${ }^{1}$ Nobuo Kido, ${ }^{1,3} \dagger$ Takayuki Komatsu, ${ }^{1} \ddagger$ Michio Ohta, ${ }^{1}$ Klaus Jann, ${ }^{3}$ Barbara Jann, ${ }^{3}$ Atsushi Saeki ${ }^{2}$ and Nobuo Kato ${ }^{1}$

Author for correspondence: Nobuo Kido. Tel: +81527815111 ext. 4782. Fax: +8152 $7828261 / 7829336$

1,2 Department of

Bacteriology ${ }^{1}$ and Second

Department of Internal

Medicine2, Nagoya

University School of

Medicine, Showa-ku

Nagoya, Aichi 466, Japan

3 Max-Planck-Institut für Immunbiologie, Freiburg, Germany

\begin{abstract}
Subcloning, transposon insertion, and deletion analysis revealed that the Escherichia coli $09 \mathrm{rfb}$ region is about $12 \mathrm{~kb}$ in size. The region encodes at least seven polypeptides of $89,74,55,50,44,41$ and $39.5 \mathrm{kDa}$. Southern hybridization analysis of $\mathrm{rb}$ regions of $E$. coli 08 and 09 , and Klebsiella 03 and 05 serotypes (all of these $O$ polysaccharides are mannose homopolymers and the structures of the repeating unit of $E$. coli 09 and Klebsiella 03 are identical) showed that a central region specific for E. coli 09 and Klebsiella 03 is flanked by two regions common to all four. Complementation experiments using strains with known defects and specific tests for the enzymic activity showed that the 50 and $55 \mathrm{kDa}$ polypeptides, encoded by the common region, are phosphomannomutase (PMM) and GDP-mannose pyrophosphorylase (GMP), respectively. Nucleotide sequencing of the region revealed the presence of two genes, $r f b K$ and $r f b M$, analogous to the corresponding genes of Salmonella typhimurium. In $E$. coli $09, r f b K$ and $r f b M$ encode proteins of 460 amino acids $(50809 \mathrm{Da})$ and 471 amino acids $(52789 \mathrm{Da})$. The amino acid sequence of GMP was conserved in RfbMs of E. coli 07 and Salmonella groups B, C1 and C2, CpsB of S. typhimurium, AlgA of Pseudomonas aeruginosa, and XanB of Xanthomonas campestris. The phylogenetic trees of PMM and GMP were different in topology and in the evolutionary distances from ancestors.
\end{abstract}

Keywords: Escherichia coli, $r f b$, phosphomannomutase, GDP-mannose pyrophosphorylase, lipopolysaccharide

\section{INTRODUCTION}

Lipopolysaccharide (LPS) is a molecule consisting of three distinct regions; lipid A, an oligosaccharide core, and an $\mathrm{O}$ polysaccharide. An $r f b$ gene cluster directs the synthesis of $\mathrm{O}$ polysaccharide of LPS (for reviews, see Jann \& Jann, 1984; Mäkelä \& Stocker, 1984; Rick, 1987). Two different pathways of $\mathrm{O}$ polysaccharide synthesis are

† Present address: Biological Systems, Department of Natural Science Informatics, School of Informatics and Sciences, Nagoya University, Chikusa-ku, Nagoya 464-01, Japan.

$\ddagger$ Present address: Department of Microbiology, Fukui Medical School, Matsuoka, Fukui 910-11, Japan.

Abbreviations: GMP, GDP-mannose pyrophosphorylase; PMM, phosphomannomutase.

The GenBank accession number for the nucleotide sequence reported in this paper is D13231. known. One found in Salmonella typhimurium involves both $r f b$ and $r f c$ genes. The individual repeat units of $\mathrm{O}$ polysaccharide are synthesized first and they are polymerized by the $r f_{c}$ gene product. Another pathway was found in Salmonella groups C1 and L, and Escherichia coli groups $\mathrm{O} 8$ and 09 . In these bacteria, the $r f e$ gene is required in addition to $r f b$ for $O$ polysaccharide synthesis. The expression of Klebsiella pneumoniae $\mathrm{O} 1$ polysaccharide has been shown recently to be $r f e$-dependent also (Clarke et al., 1992). Meier-Dieter et al. (1992) indicated that Rfe is most probably a $N$-acetyl glucosamine transferase in enterobacterial common antigen synthesis; however, the role of the $r f e$ gene in O polysaccharide synthesis is so far unclear. E. coli $\mathrm{O} 8$ and $\mathrm{O} 9$ synthesize the $\mathrm{O}$ polysaccharide by the addition of single sugars to the elongating $\mathrm{O}$ polysaccharide. In addition to E. coli $\mathrm{O} 8$ and $\mathrm{O} 9$, Klebsiella $\mathrm{O} 3$ and $\mathrm{O} 5$ are known to have mannose homopolymers as their $\mathrm{O}$ polysaccharides. The structures of the $\mathrm{O}$ poly- 
saccharide of E. coli $\mathrm{O} 9$ and Klebsiella $\mathrm{O} 3$ are identical (Jann \& Jann, 1984), and the structure of the E. coli O8 polysaccharide has been revised by Jansson et al. (1985) and is identical with that of Klebsiella O5. The repeating unit of E. coli O9 and Klebsiella O3 is $\rightarrow 3)-\alpha-\mathrm{D}-\mathrm{Man}-$ $(1 \rightarrow 3)-\alpha$-D-Man- $(1 \rightarrow 2)-\alpha$-D-Man- $(1 \rightarrow 2)-\alpha-D-M a n-$ $(1 \rightarrow 2)-\alpha$-D-Man- $(1 \rightarrow$, whereas the repeating unit of $E$. coli $\mathrm{O} 8$ and Klebsiella $\mathrm{O} 5$ is $\rightarrow 3)-\beta$-D-Man- $(1 \rightarrow 2)-\alpha$-DMan- $(1 \rightarrow 2)-\alpha$-D-Man- $(1 \rightarrow$. The non-reducing end of the $\mathrm{O}$ polysaccharide of the latter strains is 3-O-methyl-Dmannose. GDP-mannose is the mannose donor for the synthesis of these O polysaccharides (Kopmann \& Jann, 1975).

We have isolated the bis-rfb regions from these bacteria and compared them with E. coli $O 9 r f b$ by Southern hybridization. We also report on the identification of $r f b K$ and $r f b M$, responsible for the synthesis of GDP-mannose, in the common region of $E$. coli $O 9 \mathrm{rfb}$ and on the determination of their DNA sequences.

\section{METHODS}

Bacterial strains, plasmids. Bacterial strains and plasmids used in this study are listed in Table 1. A wild-type strain of E. coli CO8, and non-capsulated strains of Klebsiella K49S and K61S, which were derived from the reference strains of Klebsiella K49 (strain 6115) and K61 (strain 5710/52), respectively, were used as $r f b$ donor strains.

Media and chemicals. Bacterial cells were cultivated in L broth. $\mathrm{L}$ broth was supplemented with chloramphenicol $\left(30 \mu \mathrm{g} \mathrm{ml}^{-1}\right)$, ampicillin $\left(50 \mu \mathrm{g} \mathrm{ml}^{-1}\right)$ and tetracycline $\left(15 \mu \mathrm{g} \mathrm{ml}^{-1}\right)$ when used for the culture of bacteria carrying plasmids (Kido et al., 1989). $\mathrm{L}$ broth containing $1.5 \%(\mathrm{w} / \mathrm{v})$ agar was used for agar plates ( $\mathrm{L}$ agar). Chemicals and enzymes for the determination of phosphomannomutase (PMM) and GDP-mannose pyrophosphorylase (GMP) activities were purchased from Sigma.

Antisera. Polyclonal rabbit antisera against wild-type strains of E. coli $\mathrm{O} 8$ and $\mathrm{O} 9$, and Klebsiella $\mathrm{O} 3$ and $\mathrm{O} 5$ serotypes, were prepared by the method reported previously (Mizuta et al., 1983) and used for the slide agglutination test and immunoblot analysis. Sera were extensively adsorbed with $E$. coli K12 strains D21 A and HU1190 before use.

DNA methods. Extraction of plasmid DNA, endonuclease digestion, ligation, transformation of bacterial competent cells and electrophoresis of DNA were done according to the methods described by Sambrook et al. (1989). Large plasmid DNA was prepared by the method of Sasakawa et al. (1986). DNA was blotted from agarose gels to nitrocellulose membranes with a vacuum transfer system (Biocraft, Japan). Methods to prepare $\left[\alpha_{-}^{32} \mathrm{P}\right] \mathrm{dCTP}-$ labelled probe and conditions for Southern hybridization analysis were the same as reported previously (Komatsu et al., 1990).

The dideoxynucleotide chain-terminating method of Sanger $e t$ al. (1977) was used for DNA sequencing of M13 phage and pBluescript II SK( + ) phagemid recombinant subclones. For isolation of deleted derivatives of M13 and pBluescript II SK $(t)$ subclones, a deletion kit (Kilo-Sequence Deletion Kit, Takara shuzo) was used. Single strand phage was prepared from subclones of M13 and pBluescript II SK $(+)$ and used for the sequencing reaction. The sequencing reaction was performed by using the Sequenase Sequencing Kit (USB). Both strands were completely sequenced. Sequence data were analysed using the sDC-GENETYX system (Software Development, Tokyo,
Japan) and the ODEN program of National Institute of Genetics, Mishima, Japan.

Construction of pNKB26 plasmid carrying E. coli $09 \mathrm{rb}$. Plasmid R'-6 was digested with $B g / \mathrm{II}$ and the fragments were separated by $0.9 \%$ agarose gel electrophoresis using Agarose $\mathrm{NA}$ (Pharmacia). The $18 \mathrm{~kb}$ BglI fragment was excised from the gel and recovered by the method of Silhavy et al. (1984). The purified $B g / I I$ fragment was ligated into the BamHI site of pACYC184 and the resulting plasmid was termed pNKB26.

Isolation of the his-rfb region. bis-linked $r f b$ regions were isolated from the bacteria using a previously reported procedure (Kido et al., 1989). pULB113 was transferred from MXR(pULB113) into the $r f b$ donor strains by conjugation. The function of $\mathrm{Mu}$ phage was induced at $42{ }^{\circ} \mathrm{C}$ and then mating was carried out with the recipient strain E. coli D21A. Transconjugants carrying the bis region were selected on minimal agar medium supplemented with tryptophan and proline and with antibiotics. Slide-agglutination-positive clones were selected for further study.

Insertion mutagenesis of $\boldsymbol{E}$. coli $09 \mathbf{r} \boldsymbol{b}$. Transposon $\operatorname{Tn} 1000$ was introduced into pNKB26 according to the method of Guyer (1983). pNKB26 was introduced into JA200 carrying F::Tn 1000 by transformation. JA200 carrying pNKB26 and $\mathrm{F}:: \operatorname{Tn} 1000$ was cultivated in $\mathrm{L}$ broth until an $\mathrm{OD}_{600}$ value of approximately 0.5 was reached and mixed with the recipient strain HB101. The bacterial mixture was then dropped on $\mathrm{L}$ agar plates. Conjugation was carried out at $37^{\circ} \mathrm{C}$ for $2 \mathrm{~h}$. The bacterial growth was then streaked on $\mathrm{L}$ agar containing chloramphenicol and streptomycin. Three hundred and six independent matings were carried out. After incubation at $37^{\circ} \mathrm{C}$, one independent colony from each plate was selected. Plasmid DNA was extracted by the method of Sasakawa $e t$ al. (1986). Because Tn 1000 has one SacI site at the right end (Guyer, 1978) and pNKB26 had three SacI sites, positions of Tn 1000 insertion were assigned to $S a c \mathrm{I}$ fragments. The positions were also assigned to $S p h I$ fragments.

Identification of gene products using minicells. The minicellproducing strain P678-54 was used for the labelling of proteins encoded by pNKB26 and its derivatives. Minicells were purified by the procedure of Meagher et al. (1977) and labelled with $50 \mu \mathrm{Ci}(1.85 \mathrm{MBq})\left[{ }^{35} \mathrm{~S}\right]$ methionine $\mathrm{ml}^{-1}$. After labelling they were resuspended in $50 \mu \mathrm{l}$ sample buffer $[10 \%(\mathrm{v} / \mathrm{v})$ glycerol, $2.3 \%(\mathrm{w} / \mathrm{v})$ SDS, $62.5 \mathrm{mM}$ Tris $/ \mathrm{HCl}(\mathrm{pH} 6.8), 5 \%(\mathrm{v} / \mathrm{v}) \beta-$ mercaptoethanol) and boiled for $5 \mathrm{~min}$ before SDS-PAGE. Labelled proteins were detected by autoradiography.

Construction of phylogenetic trees. This was performed with the maximum parsimony method program written by Y. Ina, National Institute for Genetics, Mishima, Japan.

Analysis of LPS. LPS was extracted by the rapid small-scale method described previously (Kido et al., 1990; Sugiyama $e t$ al., 1990). SDS-PAGE was carried out by the method of Tsai \& Frasch (1982). Silver staining of the gel was performed by the method of Hitchcock \& Brown (1983). The method for immunoblot analysis was that reported previously (Kido $e t$ al., 1989).

Methods for the determination of PMM and GMP activities. A $0.1 \mathrm{ml}$ overnight culture was inoculated into $200 \mathrm{ml}$ fresh $\mathrm{L}$ broth and cultivated at $37{ }^{\circ} \mathrm{C}$ with vigorous shaking for $5-8 \mathrm{~h}$ (late exponential to early stationary phase). The bacteria were harvested by centrifugation at $1800 \mathrm{~g}$ for $15 \mathrm{~min}$ at $4{ }^{\circ} \mathrm{C}$. After washing once with cold saline, the cells were suspended in $3.0 \mathrm{ml}$ sonication buffer $[50 \mathrm{mM}$ Tris $/ \mathrm{HCl}(\mathrm{pH} 7.5), 1 \mathrm{mM}$ EDTA, $10 \mathrm{mM} \mathrm{MgCl}_{2}, 0.5 \mathrm{mM}$ PMSF] solutions and sonicated for $2.5 \mathrm{~min}$ ten times at $20 \mathrm{kHz}$ with an Ultrasonic Cellruptor (model UCD-130; Tosho Electronic). The sonicated suspension 
Table 1. Bacterial strains, phages and plasmids

\begin{tabular}{|c|c|c|}
\hline $\begin{array}{l}\text { Strains, phages and } \\
\text { plasmids }\end{array}$ & Relevant characteristics & Source \\
\hline \multicolumn{3}{|l|}{ Wild-type strains } \\
\hline F719 & E. coli $\mathrm{O} 9: \mathrm{K}^{-}: \mathrm{H}^{-}$ & G. Schmidt, Borstel \\
\hline $\mathrm{CO} 8$ & E. coli $\mathrm{O} 8: \mathrm{K}$ ? & This laboratory \\
\hline K49S & $\begin{array}{l}\text { K. pneumoniae } \mathrm{O} 3: \mathrm{K}_{4} 9^{-} \text {, non-capsulated mutant } \\
\text { of the reference strain of Klebsiella K49 (strain } \\
6115 \text { ) }\end{array}$ & This laboratory \\
\hline K61S & $\begin{array}{l}\text { K. pneumoniae } \mathrm{O} 5: \mathrm{K} 61^{-} \text {, non-capsulated mutant } \\
\text { of the reference strain of Klebsiella } \mathrm{K} 61 \text { (strain } \\
5710 / 52 \text { ) }\end{array}$ & This laboratory \\
\hline \multicolumn{3}{|l|}{ E. coli $\mathrm{K} 12$} \\
\hline HU1190 & $\Delta(s b c B-r f b) b s d \mathrm{R} 4$ rec $A 56 s r l:: \operatorname{Tn} 10$ & $\begin{array}{l}\text { S. Hull, Texas } \\
\text { Medical Centre }\end{array}$ \\
\hline HB101 & $\begin{array}{l}\mathrm{F}^{-} \text {bsdS20 rec } A 13 \text { ara-14 pro A2 lac Y1 galK2 } \\
\text { rpsL20 xyl-5 mtl-1 supE44 }\end{array}$ & This laboratory \\
\hline MXR & $\Delta($ lac-pro $)$ galE thi rec $A 1$ (pULB113) & A. Toussaint, Brussels \\
\hline $\mathrm{D} 21 \mathrm{~A}$ & $\begin{array}{l}\text { his-51 } \operatorname{trp}-30 \text { pro } A 23 \text { lac }-28 \text { amp } A 1 \text { str } A 173 \\
\text { tsx- } 81 \operatorname{rec} A\end{array}$ & This laboratory \\
\hline JA200 & $\mathrm{F}:: \operatorname{Tn} 1000^{+} \operatorname{trp} E 5 \operatorname{rec} A 1$ thr leuB6 lac Y & T. Sekizaki, Tsukuba \\
\hline P678-54 & thr leuB1 supE lac $Y$ ton $A$ gal mal ara mtl min & J. Hacker, Würzburg \\
\hline \multicolumn{3}{|l|}{ S. typhimurium } \\
\hline SL901 & $r f c$ & P. H. Mäkelä, Helsinki \\
\hline his-660 & $r f b K M$ & P. H. Mäkelä, Helsinki \\
\hline his-642 & $r f b K$ & P. H. Mäkelä, Helsinki \\
\hline \multicolumn{3}{|l|}{ Plasmids } \\
\hline pACYC184 & Cloning vector, $\mathrm{Tc}^{\mathrm{R}} \mathrm{Cp}^{\mathrm{R}}$ & This laboratory \\
\hline pBluescript II SK $(+)$ & Cloning vector, $A p^{R}$ & TOYOBO \\
\hline pULB113 & RP4:: miniMu & A. Toussaint, Brussels \\
\hline pNKB26 & $\begin{array}{l}\text { Derivative of a cloning vector pACYC184 } \\
\text { carrying E. coli } \mathrm{O} 9 \mathrm{rfb}\end{array}$ & This study \\
\hline $\mathrm{R}^{\prime}-\mathrm{CO} 8$ & $\begin{array}{l}\text { Derivative of pULB113, carrying bis- } r f b \text { region } \\
\text { of } \mathrm{CO} 8\end{array}$ & This study \\
\hline $\mathrm{R}^{\prime}-\mathrm{K} 49$ & $\begin{array}{l}\text { Derivative of pULB113, carrying bis-rfb region } \\
\text { of K49S }\end{array}$ & This study \\
\hline $\mathrm{R}^{\prime}-\mathrm{K} 61$ & $\begin{array}{l}\text { Derivative of pULB113, carrying bis }-r f b \text { region } \\
\text { of K } 61 \mathrm{~S}\end{array}$ & This study \\
\hline \multicolumn{3}{|c|}{ 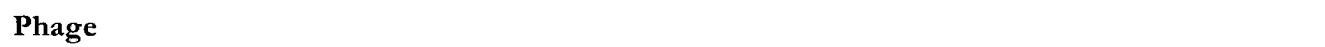 } \\
\hline$\Omega 9$ & Recognizes strains containing $E$. coli O9 LPS & G. Schmidt, Borstel \\
\hline
\end{tabular}

was centrifuged at $20000 \mathrm{~g}$ for $30 \mathrm{~min}$ at $4{ }^{\circ} \mathrm{C}$. The supernatants were used for enzymic analysis. Protein concentration of cell extracts was determined by the Bio-Rad Protein Assay (BioRad) as instructed by the manufacturer. Bovine serum albumin was used as the protein reference substance.

The method of Sá-Correia et al. (1987) was used to determine PMM activity. The $2.0 \mathrm{ml}$ reaction mixture contained $0 \cdot 1 \mathrm{M}$ Tris/ $\mathrm{HCl}$ buffer ( $\mathrm{pH} 7 \cdot 5$ ), $20 \mu \mathrm{mol} \mathrm{MgCl}_{2}, 0.5 \mu \mathrm{mol} \alpha$-Dglucose-1,6-diphosphate, $1.0 \mathrm{U}$ each of phosphoglucose isomerase, glucose 6-phosphate dehydrogenase and phosphomannose isomerase, and $2 \mu \mathrm{mol}$ NADP. The reaction was started by the addition of $200 \mu \mathrm{l}$ crude extract and $2 \mu \mathrm{mol} \alpha$ $\mathrm{D}(+)$-mannose-1-phosphate. Increases in $\mathrm{OD}_{340}$ were recorded at $37{ }^{\circ} \mathrm{C}$ with a UV2200 UV-VIS recording spectrophotometer (Shimadzu). Enzyme activities were calculated after subtraction of endogenous activities which were measured in an assay without $\alpha$ - $\mathrm{D}(+)$-mannose-1-phosphate.
GMP activity was measured by the method of Munch-Petersen (1962). The $1.0 \mathrm{ml}$ reaction mixture contained $0.05 \mathrm{M}$ Tris $/ \mathrm{HCl}$ buffer (pH 7.5), $10 \mu \mathrm{mol} \mathrm{MgCl}_{2}, 0 \cdot 1 \mu \mathrm{mol} \mathrm{ADP}, 2 \mu \mathrm{mol}$ pyrophosphate, $5 \mu \mathrm{mol}$ sodium fluoride, and $0.5 \mathrm{U}$ each of hexokinase, nucleoside- $5^{\prime}$-diphosphate kinase, and glucose 6-phosphate dehydrogenase, $0 \cdot 8 \mu \mathrm{mol}$ glucose and $1 \mu \mathrm{mol}$ NADP. The reaction was started by the addition of $50 \mu \mathrm{l}$ crude extract and $0.4 \mu \mathrm{mol}$ GDP-D-mannose. The reduction of NADP was measured at $340 \mathrm{~nm}$ as described above. Enzyme activities were calculated after subtraction of endogenous activities which were measured in an assay without pyrophosphate.

\section{RESULTS AND DISCUSSION}

\section{Molecular cloning of the $r \mathrm{fb}$ region of $E$. coli 09}

The $r f b$ region $\left(r f b_{\mathrm{EOg}}\right)$ of $E$. coli O9 strain $\mathrm{F} 719$ was predicted to be in a $17.7 \mathrm{~kb} B g / \mathrm{II}$ fragment of plasmid 
(a)
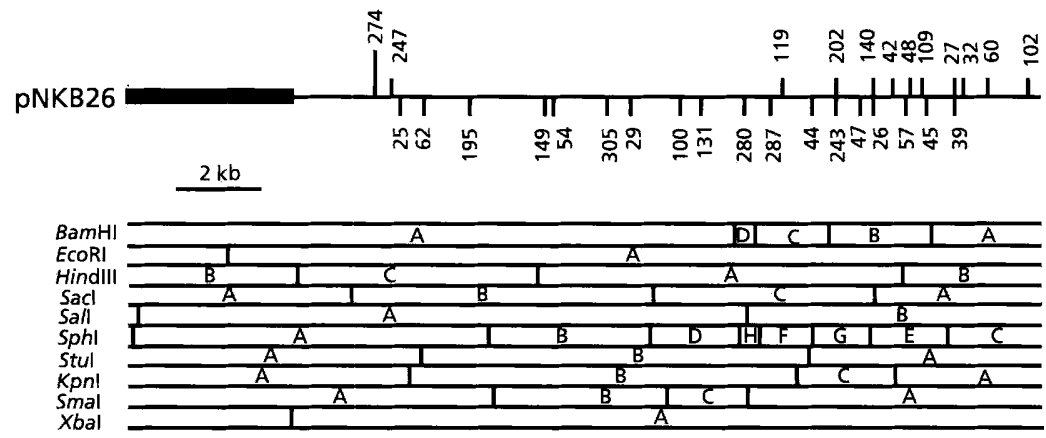

(b)

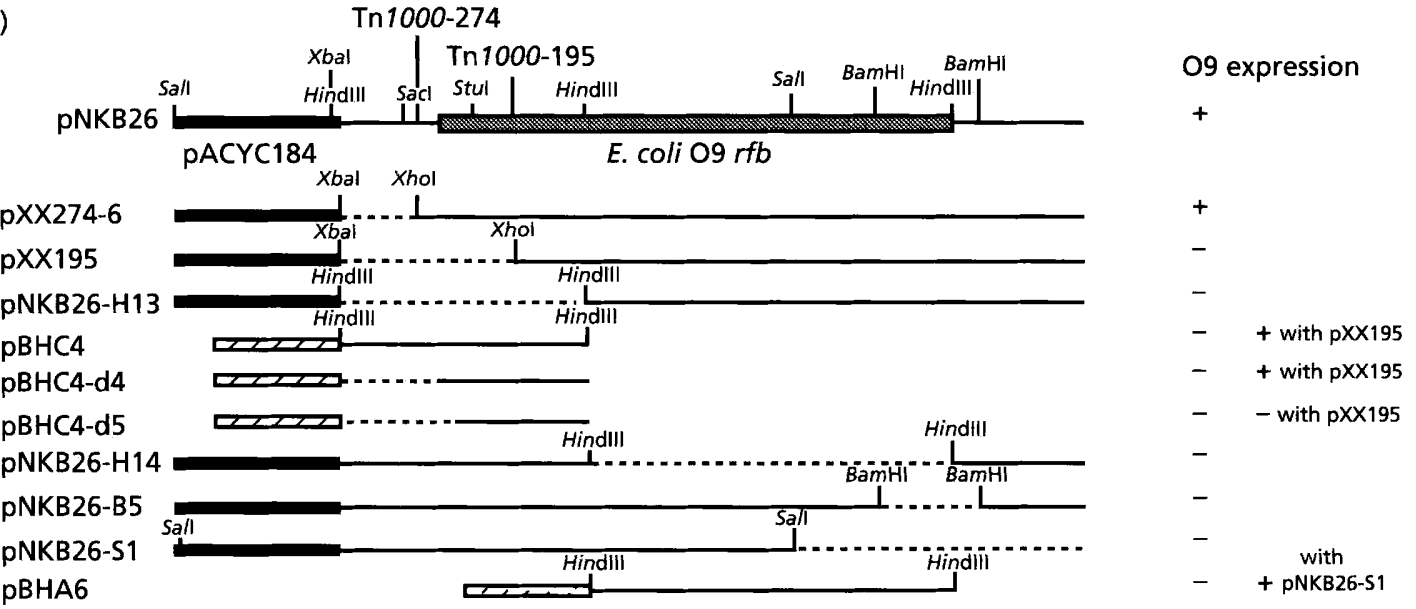

Fig. 1. (a) Restriction enzyme map of pNKB26. The numbers indicate Tn1000 insertion plasmids and show the positions of Tn 1000 insertions. Plasmids that still direct the synthesis of 09 polysaccharide are shown above the line of pNKB26 and those which do not are shown below. (b) Physical map of subclones and deletion plasmids used in the study. Solid bars represent the cloning vector pACYC184; hatched bars represent the cloning vector pBluescript II SK(+). Dotted lines represent deleted regions. A series of pXX plasmids with various deletions was prepared using an Xhol site in Tn1000 and an Xbal site of PACYC184, by removing the Xbal-Xhol fragment from various plasmids. Other deletion plasmids were prepared by partial digestion with each enzyme. HindIII $A$ and $C$ fragments were subcloned into a HindIII site of pBluescript II SK(+) termed pBHA6 and pBHC4, respectively. Deletion derivatives of pBHC4 were prepared by digestion with Apal and Xhol, and deletions originating at the Xhol site were introduced by exonuclease III and mung bean nuclease treatment (Deletion kit, Takara Shuzo Co.). Synthesis of 09 polysaccharide was determined by SDS-PAGE and immunoblot analysis and the results are shown on the right. The deduced $E$. coli $09 \mathrm{rfb}$ region is shown by the shaded bar.

R'-6 (Kido et al., 1989). The Bg/II fragment was cloned into the BamHI site of pACYC184 and the newly constructed plasmid, $\mathrm{pNKB} 26$, was introduced into the $r f b$ deletion strain HU1190, a rec ${ }^{-} b s d \mathrm{R}$ derivative of E. coli K12 SФ874 (Haraguchi et al., 1991). The resulting strain gave positive agglutination with $E$. coli $\mathrm{O} 9$ antiserum and was sensitive to $E$. coli $O 9$-specific phage $\Omega 9$, whilst the host strain was not agglutinated and was resistant. The LPS profile from SDS-PAGE analysis and the serological properties of HU1190 harbouring pNKB26 were identical to those seen in an E. coli $O 9$ wild-type strain and D21A(R'-6) (Kido et al., 1989; Saeki et al., 1993). The LPS profile showed the presence of a typical ladder of bands corresponding to lipid A plus core oligosaccharide substituted with $O$ polysaccharide. The results showed that $\mathrm{pNKB} 26$ carried the whole $r f b$ region for the synthesis of $\mathrm{O} 9$ polysaccharide and that there was no contribution of host $r f b$ genes to the synthesis of $\mathrm{O} 9$ polysaccharide in
E. coli $\mathrm{K} 12$. We used $\mathrm{pNKB} 26$ for further analysis of the $r f b$ region.

\section{Isolation and characterization of $\operatorname{Tn} 1000$ insertion derivatives of pNKB26}

To determine the precise region boundaries of $r f b_{\mathrm{EO} 9}$, we isolated $\operatorname{Tn} 1000$ insertion derivatives of $\mathrm{pNKB} 26$. Representative Tn1000 insertion plasmids were selected and their insertion sites are shown in Fig. 1(a). From the results it appears that the left end of $r f b_{\mathrm{EO}}$ is located between positions 25 and 247 . However, the right end of $r f b$ was not clear from the results because some insertion derivatives that had $\operatorname{Tn} 1000$ insertions in this region of pNKB26 directed the synthesis of O9 polysaccharide, whilst others with insertions at almost the same positions did not. To clarify the situation, we prepared subclones of pNKB26 for analysis. 


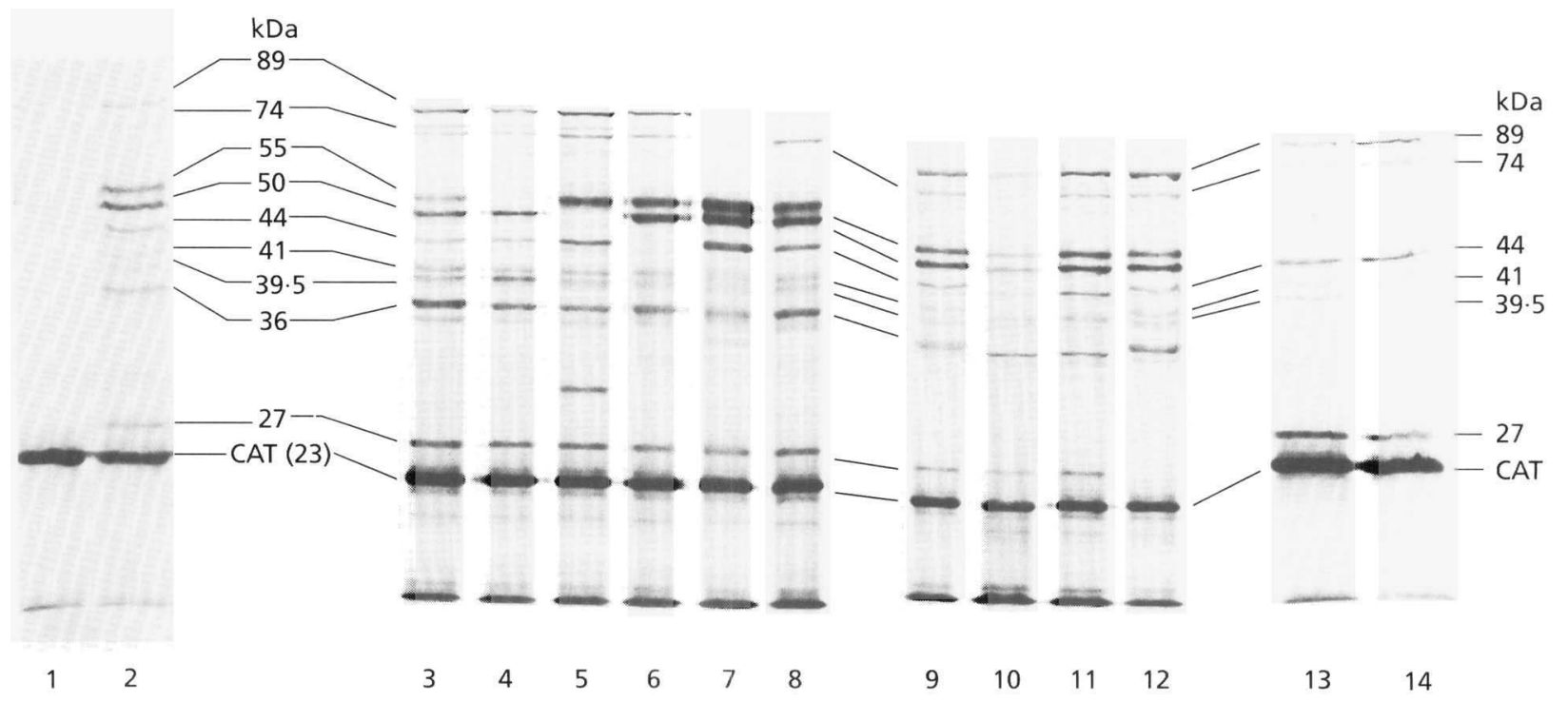

Fig. 2. Minicell analysis of pNKB26. Lanes: 1 , pACYC184; 2, pNKB26; 3, pNKB26::Tn1000-274 (O9 positive control for Tn1000 inserted in pNKB26); 4, pNKB26::Tn1000-62; 5, pNKB26::Tn1000-195; 6, pNKB26::Tn1000-54; 7, pNKB26::Tn1000-305; 8, pNKB26::Tn1000-131; 9, pNKB26; 10, pNKB26::Tn1000-243; 11, pNKB26::Tn1000-47; 12, pNKB26::Tn1000-48; 13, pXX195; 14, pNKB26-H13. The size of each polypeptide (kDa) is indicated on the right. CAT, chloramphenicol acetyl transferase encoded by the vector.

\section{Subcloning of pNKB26}

Deletion derivatives and subclones of $\mathrm{pNKB} 26$ are shown in Fig. 1(b). pXX274-6, having a deletion between the vector and Tn1000 insertion position 274 , directed the synthesis of $\mathrm{O} 9$ polysaccharide. However, plasmids with more extended deletions, pXX195 and pNKB26H-13, did not direct the synthesis of $\mathrm{O} 9$ polysaccharide. We constructed some subclones using pBluescript II SK(+), as these are compatible with pACYC184-based deletion derivatives (the former has a ColE1 replicon, whilst the latter has a P15A replicon). When plasmids pBHC4 (Fig. 1) and pXX195 were put into HU1190, the resulting strain synthesized O9 polysaccharide. Plasmids with various lengths of deletions from the left side of the fragment of $\mathrm{pBHC} 4$ were prepared and their ability to synthesize $\mathrm{O} 9$ polysaccharide was analysed by co-transformation with pXX195. From the results, the left end of $r f b_{\mathrm{EOg}}$ was determined to be between the left ends of pBHC4-d4 and -d5, almost the same as that of Tn 1000 insertion position 25 .

Other plasmids with deletions at the right end of pNKB26 were examined. pNKB26-H14, pNKB26-B5 and pNKB26-S1 did not direct the synthesis of O9 polysaccharide. We put plasmid pBHA6 (Fig. 1) together with pNKB26-S1 into strain HU1190. This strain synthesized $\mathrm{O} 9$ polysaccharide and, because no deletion plasmids of pBHA6 could substitute for $\mathrm{pBHA}$, the whole region of the Hindiil A fragment must be necessary for synthesis of O9 polysaccharide. Thus, we concluded that the minimum region essential for $\mathrm{O} 9$ polysaccharide synthesis lies between the Tn 1000 insertion position 247 and the right end of the HindIII A fragment of pNKB26, and is about $12 \mathrm{~kb}$ (Fig. 1b). Expression of the O9 polysaccharide inspite of $\operatorname{Tn} 1000-119$ within the $12 \mathrm{~kb}$ fragment is thought to be due to its insertion into a non-essential region. Some clones carrying Tn1000 insertions well outside the $r f b_{\mathrm{EO} 9}$ region, but nevertheless inhibiting $\mathrm{O}$ polysaccharide synthesis, were also isolated. The same phenomenon was observed by Kessler et al. (1991). These authors cloned the $r f b$ region from Yersinia psendotuberculosis serotype II A and located the $r f b$ region by Tn 5 mutagenesis. They isolated one clone carrying a transposon insertion outside the region for $\mathrm{O}$ polysaccharide synthesis, but inhibiting $\mathrm{O}$ polysaccharide production. The question of whether the actual transposon insertion, or a second mutational event within the $r f b$ region, caused this effect, was not investigated. Transposon insertion derivatives of pNKB26, pNKB26::Tn1000-57, -45 and -39 carrying transposon insertions outside the minimal region for $\mathrm{O} 9$ polysaccharide synthesis blocked $\mathrm{O} 9$ polysaccharide synthesis. A subclone carrying a $S a c \mathrm{I}-S_{a}$ l fragment which covers this region did not confer the ability to synthesize $\mathrm{O} 9$ polysaccharide to these strains. Minicell and maxicell analyses revealed that the $50 \mathrm{kDa}$ polypeptide, shown to be PMM in this study, was missing (data not shown). The $r f b K$ gene for PMM is not located near these transposon insertions. These results suggested that the second mutational event(s) in $r f b K$ may cause the loss of $\mathrm{O}$ polysaccharide synthesis in these strains. However, it is not clear why a Tn1000 insertion outside $r f b_{\text {EOg }}$ inhibits synthesis of PMM distant from the insertion positions.

\section{Analysis of ${ }^{35} \mathrm{~S}$-labelled proteins encoded by pNKB26 in minicells}

Minicell analysis was carried out to determine the number and size of polypeptide gene products encoded by $r f b_{\mathrm{EO}}$. pNKB26 encoded nine major polypeptides with mol- 


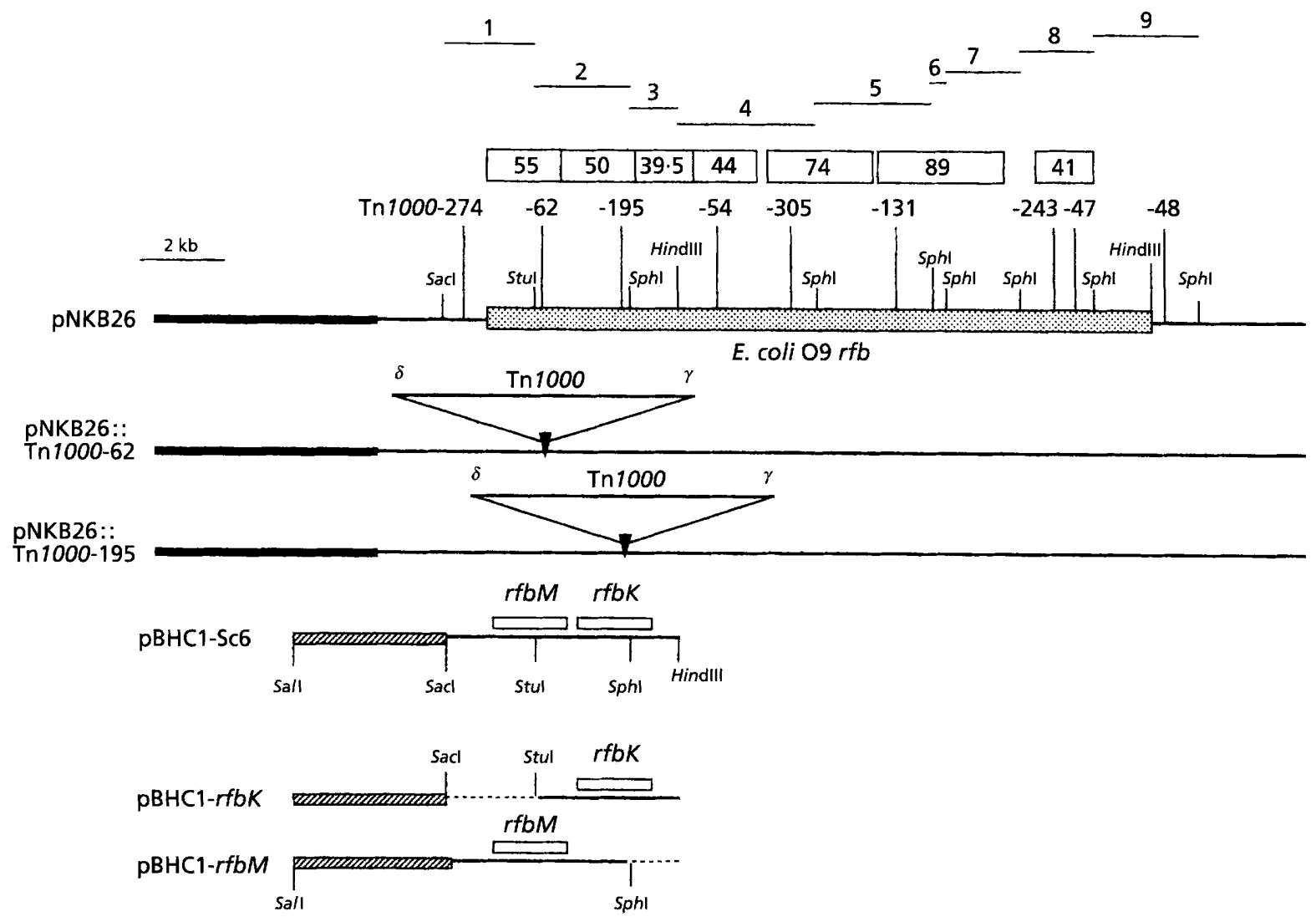

Fig. 3. Physical maps of plasmids used for the determination of PMM and GMP activities. A Sacl-HindIII fragment of pNKB26 was subcloned into pBluescript II SK(+) and named pBHC1-Sc6. pBHC1-rfbK and pBHC1-rfbM were constructed by deleting a Sacl-Stul and a Sphl-Sall fragment from $\mathrm{pBHC1}-\mathrm{Sc} 6$, respectively. Numbers in boxes represent the molecular mass of polypeptides and their gene location deduced by minicell analysis. Numbered bars at the top represent DNA fragments used for Southern hybridization analysis.

ecular masses of $89,74,55,50,44,41,39 \cdot 5,36$ and $27 \mathrm{kDa}$ in addition to the chloramphenicol acetyltransferase (CAT) of the cloning vector (Fig. 2, lanes 1 and 2). The locations of genes encoding these polypeptides were determined by minicell analysis of the Tn 1000 insertion derivatives of pNKB26. Because Tn 1000 has termination codons at both ends, $\operatorname{Tn} 1000$ insertion into coding DNA terminates protein synthesis and causes a change of molecular mass of the gene product (Sancar et al., 1981). Some extra polypeptides derived from $\operatorname{Tn} 1000$ were detected in the minicell preparations of the $\operatorname{Tn} 1000$ insertion plasmid (Fig. 2, lane 3). The locations of genes for six polypeptides of $89,74,55,50,44$ and $27 \mathrm{kDa}$ were ascertained (Fig. 2, lanes 4-8 and 12). The gene for the polypeptide of $27 \mathrm{kDa}$ was located at $\operatorname{Tn} 1000$ insertion position 48 outside of $r f b_{\mathrm{EO}}$ (Fig. 1). A polypeptide of 41 or $39.5 \mathrm{kDa}$ was absent in preparations of pNKB26:: Tn1000-243 and -47 (Fig. 2, lanes 10 and 11). However, it was difficult to determine the molecular mass of the band because the mobility differed slightly in the preparations of $\mathrm{O}$ polysaccharide-positive and -negative minicell preparations due to the effect of LPS in the preparations. The location of the gene for the $39 \cdot 5 \mathrm{kDa}$ polypeptide was determined as follows. The polypeptide was absent from the pNKB26-H13 preparation (Fig. 2, lane 14) but present in the pXX195 preparation (Fig. 2, lane 13). The gene for the $39.5 \mathrm{kDa}$ polypeptide was therefore located in the deleted fragment. The gene for the polypeptide of $41 \mathrm{kDa}$ might be located at insertion positions 243 and 47 . The location of the gene for the polypeptide of $36 \mathrm{kDa}$ was not determined but it is probably between the vector and Tn 1000 insertion 274 because only a faint band was observed in the pXX195 preparation. From these results, at least seven polypeptides of $89,74,55,50,44,41$ and $39 \cdot 5 \mathrm{kDa}$ are encoded by $r f b_{\mathrm{EO}}$, implicating them in the synthesis and assembly of the O9 polysaccharide. Since $\left[{ }^{35} \mathrm{~S}\right] \mathrm{methionine}$ was used, it is also possible that polypeptides lacking methionine or others produced in very low amounts are also involved in $\mathrm{O} 9$ polysaccharide synthesis and have not been detected. The sum of the sizes of the seven polysaccharides accounts for a coding region of about $10 \cdot 7 \mathrm{~kb}$ of DNA, assuming that there are no overlaps and no non-coding regions between structural genes. It may be possible that there are some genes in the remaining $1.3 \mathrm{~kb}$ of the approximately $12 \mathrm{~kb} r f b_{\mathrm{EO}}$ region. The deduced locations of the genes are shown in Fig. 3.

Two polypeptides of 74 and $89 \mathrm{kDa}$ were absent from the pNKB26::'Tn1000-305 preparation (Fig. 2, tane 7) but 
(a)

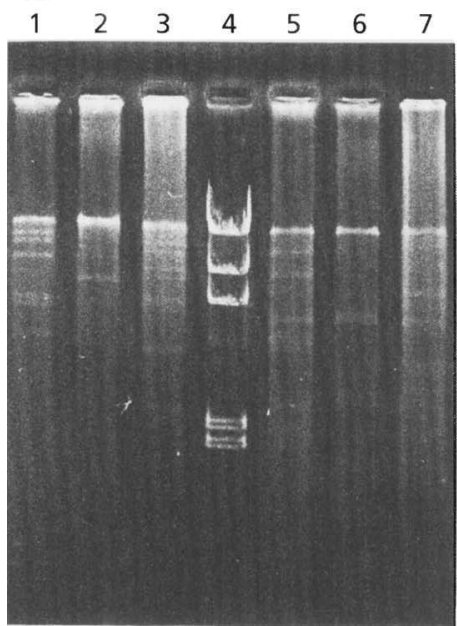

(b)

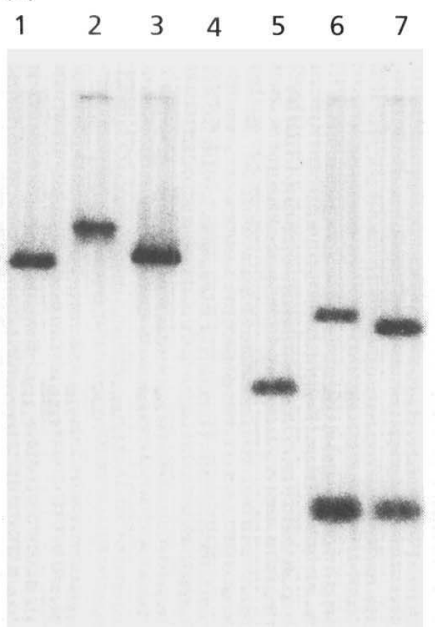

(c)

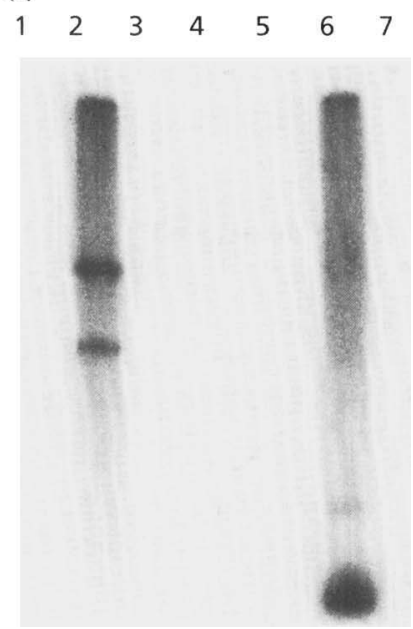

Fig. 4. (a) Ethidium bromide-stained agarose gel. Lanes: 1 and $5, R^{\prime}-C O 8 ; 2$ and $6, R^{\prime}-K 49 ; 3$ and $7, R^{\prime}-K 61 ; 4, H i n d I I I-$ digested $\lambda$ DNA. DNA preparations were digested with EcoRI (lanes 1-3) or Pstl (lanes 5-7). (b, c) Autoradiograms of gels with DNA fragment 3 (b) or 5 (c) (see Fig. 3).

Table 2. Summary of the results of Southern hybridization analysis

\begin{tabular}{|cccc|}
\hline $\begin{array}{c}\text { Probe } \\
\text { DNA* }\end{array}$ & $\begin{array}{c}\mathbf{R}^{\prime} \text {-CO8 } \\
(\text { E. coli } \\
\text { O8) } \dagger\end{array}$ & $\begin{array}{c}\mathbf{R}^{\prime}-\text { K49S } \\
\text { (Klebsiella } \\
\text { O3) } \dagger\end{array}$ & $\begin{array}{c}\mathbf{R}^{\prime} \text {-K61S } \\
\text { (Klebsiella } \\
\text { O5) } \dagger\end{array}$ \\
\hline 1 & + & + & + \\
2 & + & + & + \\
3 & + & + & + \\
4 & - & + & - \\
5 & - & + & - \\
6 & - & + & - \\
7 & $+{ }^{w}$ & + & $+{ }^{w}$ \\
8 & + & + & + \\
9 & + & + & + \\
\hline
\end{tabular}

* Probes are shown in Fig. 3.

$t+$, Positive; $+{ }^{w}$, hybridized weakly; - , negative.

only the $89 \mathrm{kDa}$ preparation was absent from the pNKB26:: Tn1000-131 preparation (Fig. 2, lane 8), suggesting that the genes were transcribed from one promoter from the gene for the $74 \mathrm{kDa}$ polypeptide towards that for the $89 \mathrm{kDa}$ polypeptide. Other Tn 1000 insertion plasmids lost only one protein band from the preparations, indicating that other genes may have their own promoters. These observations support the idea that the O9 LPS region is organized as a gene cluster, as observed in the O7 LPS region by Marolda et al. (1990), rather than a single operon.

\section{Southern hybridization analysis of $\boldsymbol{r} \boldsymbol{f b}$ genes}

In a number of E. coli and Klebsiella strains the rfb gene cluster has been cloned and shown to be linked to his
Table 3. Complementation test of mutations in E. coli $09 \mathrm{rfb}$ by $\mathrm{rfbK}$ and $\mathrm{rfbM}$ genes of the $S$. typhimurium rfb cluster

\begin{tabular}{|lcccc|}
\hline Plasmids* & \multicolumn{5}{c|}{ E. coli O9 expression $\dagger$ in: } \\
\cline { 2 - 5 } & $\begin{array}{c}\text { HU1190 } \\
\left(r f b K^{-}\right.\end{array}$ & $\begin{array}{c}\text { SL901 } \\
\left(r f b K^{+}\right.\end{array}$ & $\begin{array}{c}\text { his-660 } \\
\left(r f b K^{-}\right.\end{array}$ & $\begin{array}{c}\text { his-642 } \\
\left(r f b K^{-}\right.\end{array}$ \\
& $\left.r f b M^{-}\right)$ & $\left.r f b M^{+}\right)$ & $\left.r f b M^{-}\right)$ & $\left.r f b M^{+}\right)$ \\
\hline pNKB26 & + & + & + & + \\
pNKB26:: Tn1000-62 & - & + & - & + \\
pNKB26:: Tn1000-195 & - & + & \pm & \pm \\
pXX195 & - & + & - & \pm \\
\hline
\end{tabular}

* Plasmid maps are shown in Figs 1 and 3.

$\dagger$ E. coli $\mathrm{O} 9$ expression was determined by an agglutination test in anti-E. coli $\mathrm{O} 9$ serum and was confirmed by the silver-stained SDSPAGE gel method and immunoblot analysis of LPS preparations. + , Positive; - , negative; \pm , trace amount.

(Clarke \& Whitfield, 1992; Kido et al., 1989; Valvano \& Crosa, 1989). R' plasmids carrying the bis-rfb regions of E. coli O8 (strain CO8), and Klebsiella O3 (strain K49S) and $\mathrm{O} 5$ (strain K61S) were isolated according to the method reported previously and termed $\mathrm{R}^{\prime}-\mathrm{CO} 8, \mathrm{R}^{\prime}-\mathrm{K} 49$ and $\mathrm{R}^{\prime}-\mathrm{K} 61$, respectively (Kido et al., 1989; Saeki et al., 1993). Strain D21 A, carrying these plasmids, agglutinated with antisera against the parental strains. DNA homologies among $r f b$ genes of these bacteria were investigated by Southern hybridization using DNA fragments of $r f b_{\mathrm{EO}}$ as probe. Plasmid preparations were digested with restriction enzymes EcoRI and $P_{s t} \mathrm{I}$ and separated by $0.9 \%$ agarose gel electrophoresis (Fig. 4a) and probed with DNA fragments of $r f b_{\text {EOg. }}$. Represen- 


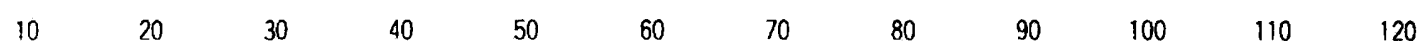
AAATGCGGAAGTGTGGTGCGTITGGCGGCCAGGTGAGGGAAGAGCATGTTAAAAGCAGAGATATGCCTGAAGGTATATCTCTGCTTTTAGGTTTTCAGGACACGCGTTCCGCCCGGCTG

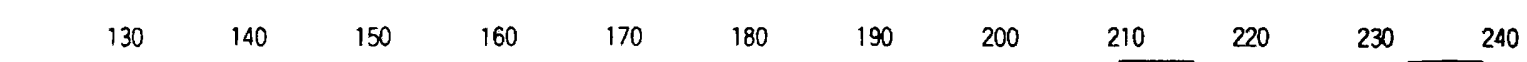

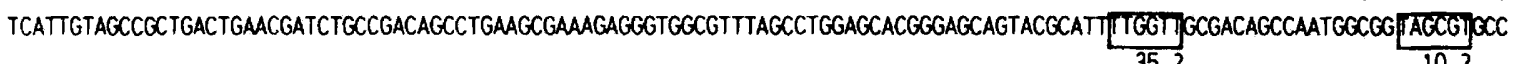

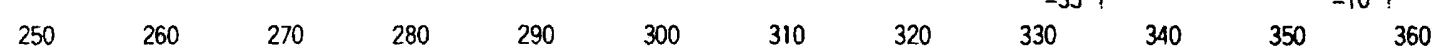
TGAAAAAGGCCGTTCCACCCAGACGGTCGATTGATTGATAGTAAAATAAAGCAATTATTTATTIAAGGATTTCATTATGTTACTCCCTGTAATTATGGCTGGTGGTACCGGCAGTCGTCT SD M L L P V I H A G G T G S R L start rfbw

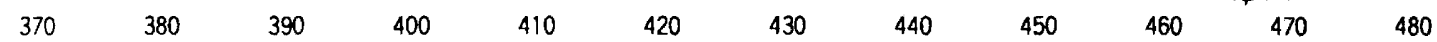
CTGCCCGATGTCTCGCGAGCTTTACCCGAAACAGTTCCTCCGCCTGTTCGGCCAGAACTCCATGCTGCAGGAAACCATCACCCGACTCTCGGGCCTTGAAATCCATGAACCGATGGTCAT W P S R E L Y P K O F L R L F G O N S M L Q E T I T R L S GLE I HE P M I $490 \quad 500 \quad 510 \quad 520 \quad 530 \quad 540 \quad 550 \quad 560 \quad 570 \quad 580 \quad 590 \quad 600$ CTGTAACGAAGAGCACCGCTTCCTGGTGGCCGAACAGCTGCGCCAGCTCAACAAGCTGTCGAACAACATTATTCTTGAGCCGGTCGGGCGCAACACCGCCCCGOCCATCGCCCTGGCGGC C N E E H R F L V A E O L R O L N K L S N N I I L E P V G R N TA P A I A L A A

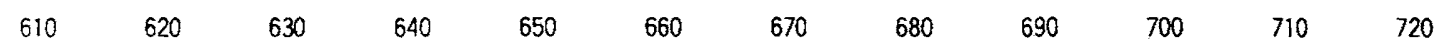
CCTTCAGCCCACCCGTCACGGCGATGACCCGCTGATGCTGGTCCTCGCCGCCGACCATATCATCAATAACCAGCCGGTCTTCCACGACGCCATCCOCGTCGCCGAGCAGTATGCCGATGA

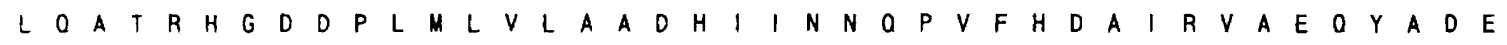

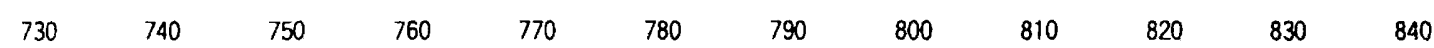
AGGCCATCTGGTCACCTTCGGTATCGTGCCGAACGCCCCGGAAACCGGCTACGGCTACATCCACCGCGGCGTGGCCCTCACCGACAGCGCCCACACCCCGTACCAGGTGGCCCGCTTCGT G H L V T F G I V P N A P E T G Y G Y I O R R G V A L T D S A H T

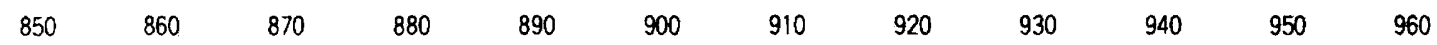
GGAGAAGCCGGACCGCGAGCGCGCCGAGGCCTACCTCGCCTCCGGGGAGTACTACTGGAACAGCGGCATGTTTATGTTCCGCGCCAAAAAATACCTCTCCGAGCTGGCCAAATTCCGCCC

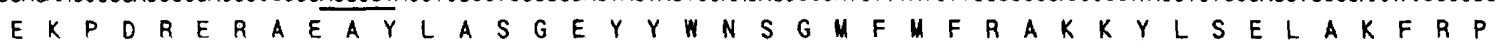

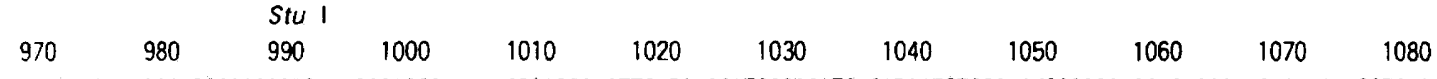
GGATATCCTCGAAGCCTGCCAGGCCGCGGTCAATGCCGCCGATAACGGCAGCGACTTCATCAGCATCCCGCATGACATTTTCTGCGAGTGCCCGGACGAGTCCGTGGACTACGCGGTGAT D I L E A C O A A V N A A D N G S D F I S I P H D I F C E C P D E S V D Y A V M

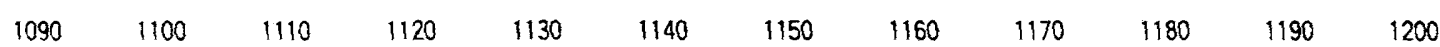
GGAGAAAACCGCCGACGCGGTGGTGGTCGGTCTCGATGCCGACTGGAGCGACGTCGGCTCCTGGTCCGCCCTGTGGGAGGTCAGCCCGAAAGACGGGCAGGGCAACGTCCTCAGCGGCGA E K T A D A V V V G L D A D W S D V G S W S A L W E V S P K D G O G

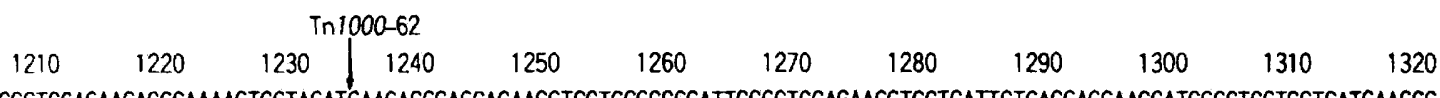
CGCGTGGGTCCACAACAGCGAAAACTGCTACATCAACAGCGACGAGAAGCTGGTGCCGGCCATTGGCGTGGAGAACCTGGTGATTGTCAGCACCAAGGATGCCGTGCTGGTGATGAACCG A W V H N S E N C Y I N S D E K L V A A I G V E N L V I V S T K D A V L V M N R

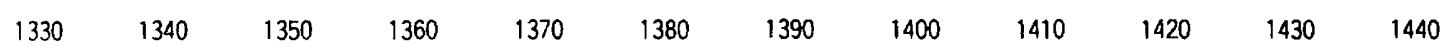
TGAGCGTTCCCAGGACGTGAAGAAGGCGGTCGAGTTCCTCAAGCAGAACCAGCGCAGCGAGTACAAGCGCCACCGCGAGATTTACCGTCCCTGGGCCCGCTGCGACGTGGTGGTCCAGAC

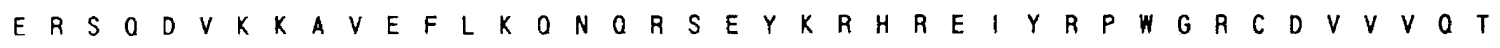

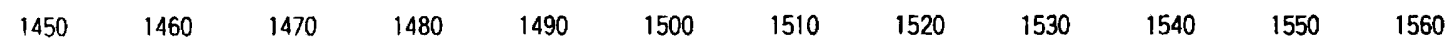
CCCOCGCTTCAACGTCAACCGCATCACCGTGAAACCGGGCGGCGCCTTCTCGATGCAGATGCACCACCACCGCGCCGAGCACTGGGTCATTCTCGCCGGCACCGGCCAGGTGACGGTCAA P R F N V N R I T V K P.G G A F S M O M H H H R A E H W V I L A G T G O V T V N

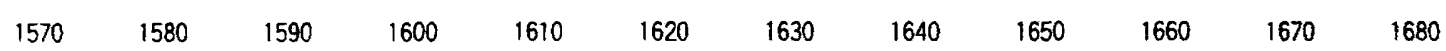
CGGCAAGCAGTTCCTGCTGACCGAGAACCAGTCCACCTTTATTCCGATTGGCGCCGACCACAGCCTGGAAACCCGGGCCGCATTCCGCTGGAAGTGCTGGAGATCCAGTCGGGGTCGTA $G K O F L L T E N O S T F|P| G A E H S L E N P G$ I $P$ I Sma 1

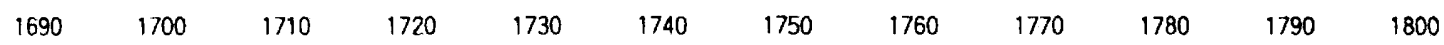
CCTCGGCGAGGACGACA TATTGGTATAAAGACCAG ETGGTGGTGCTAATTTTCGGGACAAAACGCAGAATGACACAGTTAACATGCTTTAAGGCTTATGACATCCGTGGTGAAC $-35 ?$ ?

$L G E D D I I R I K D O Y G R C * \quad$ M T O L T C F K A Y D I R G EL start $r f b K$

Fig. 5. For legend see facing page. 


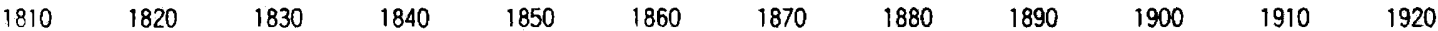
TGGGCGAGGAGCTGAACGAGGACATCGCCTACCGTATCGCCCGCQCCTATGGCGAATTTCTGAAACCCGGGAAGATAGTGGTGGGGGGCGATGTGCGCCTCACCAGCGAGTCGCTGAAGC

$G E E L N E D$ I A Y R I G R A Y G E F L K P G K I V V G G D V R L T S E S L K L

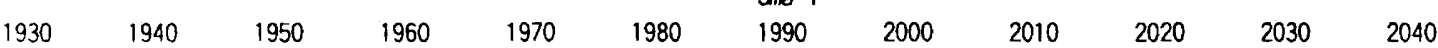
TGGCGCTGGCCCGCGGGCTGATGGACGCCGGCACCGACGTGCTGGATATTGGCCTGAGCGGCACGGAAGAGATTTACTTCGCCACTTTCCACCTCGGGGTGGACGGCGGCATCGAGGTGA

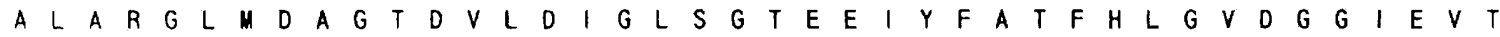

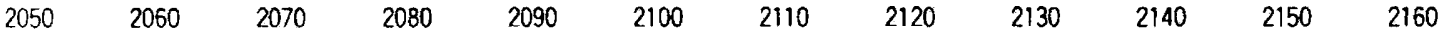
CGGCCAGCCACAACCCGATGAACTACAACGGCATGAAGCTGGTGCGCGAGAACGCGAAGCCCATCAGCGGCGACACCGGCCTGCGGGATATCCAGCGCCTGGCGGAGGAGAATCAGTTCC

A S H N P M N Y N G M K L V R E N A K P I S G D T G L R D I O R L A E E N 0 F $P$

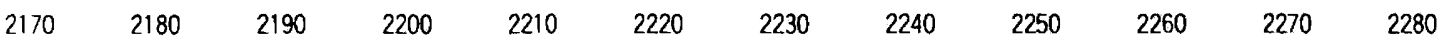
CGCCGGTGGACCCGGCGCGTCGCGGGACCCTCCGCCAGATTTCGGTGCTGAAGGAGTACGTTGACCACCTGATGGGCTATGTGGACCTGGCGAACTTCACCCGTCCGCTGAAGCTGGTGG

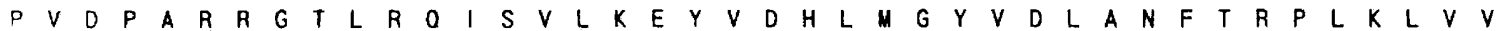

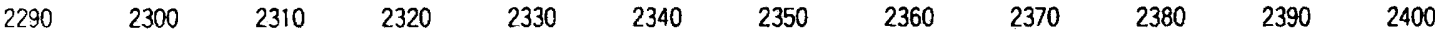
TGAACTCCGGCAACGGGGCGGCGGGGCACGTGATTGATGAGGTGGAGAAACGCTTCGCGGCGGCCGGGGCGCCGGTGACCTTTATCAAGGTECATCACCAGCCGGACGGCCATTTTCCGA $N S G$ N G A A G H V I D E V E K R F A A A G A P V T F I K V H H O P D $G$ H $F$

$2410 \quad 2420 \quad 2430 \quad 2440 \quad 2450 \quad 2460 \quad 2470 \quad 2480 \quad 2490 \quad 2500 \quad 2510 \quad 2520$ ACGGTATCCCGAACCCGCTGCTGCCGGAGTGCCGCCAGGACACCGCCGACGCGGTGCGTGCACATCAGGCGGACATGGGTATCGCCTTTGACGCCGACTTCGACCGCTGCTTCCTGTTCG $G$ I $P$ N $P$ P L L P E C R O D T A D A V R A H O A D M G I A F D G D F In $1000-195$

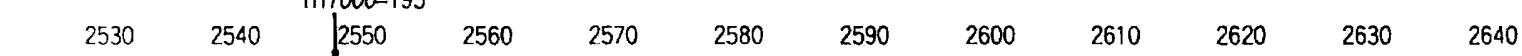
ATGACGAGGCGTCGTTTATCGAGGGGTACTACATTGTCGGCCTGCTGGCGGAGGCGTTCCTGCAGAAGCACCCGGGGGCGAAAATCATTCACGACCCGCGTCTGACGTGGAACACGGTGG D E A S F I E G Y Y I V G L L A E A F L O K O P G A K I I H D P $R$ L $T$ T W $N$ T V D $2650 \quad 2660 \quad 2670 \quad 2680 \quad 2690 \quad 2700 \quad 2710 \quad 2720 \quad 2730 \quad 2740 \quad 2750 \quad 2760$ ACATCGTGACCCGCAGCGGCGGCCAGCCGGTGATGTCGAAGACCGGGCATGCGTTCATCAAGGAGCGGATGCCCCAGGAAGACGCTATCTACGGCGGGGAGATGAGTGCGCACCATTACT I V T R S G G O P V N S K T G H A F I K E R M R O E D A I Y G G E H S A H H Y F

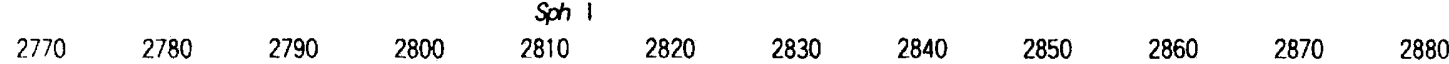
TCCGCGACTTCGCCTACTGCGACAGCGGGATGATCCCGTGGCTCCTGGTGGCGGAGCTOCTGTGCCTGAAGAACAGTTCGCTGAAATCGCTGGTGCCGGACCGCCAGGCGGCGTTCCCGG R D F A Y C D S G M I P W L L V A E L L C L K N S S L K S L V A D R A A A F

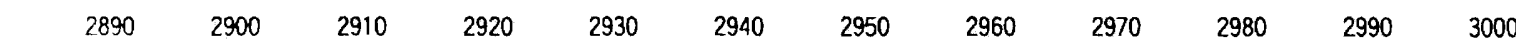
CGTCGGGGGAGATCAACCGCAAGCTGGGAAATCGGGCGGAGGCGATAGCGCGCATCCGGGCGCAGTATGAGCCGGCGGCCGCACACATCGACACAACGGACGGTATCAGTATTGAATACC $S$ G E I N R K L G N A A E A I A R I R A O Y

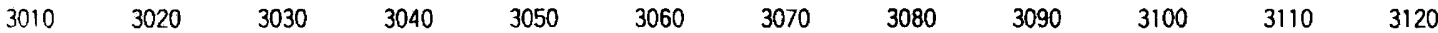
CTGAGTGGCGCTITAACCTGCGCACGTCCAACACGGAGCCGGTGGTGCGTCTGAACGTTGAGTCCAGAGCGGATACTGCGTTAATGAATGAGAAACCGCCGAGCTGCTCAACCTGTTAA E W R F N L R T S N T E P V V R L N V E S R A D T A L M N E K T A E L L $N L L K$

3130 AAGAGGAATCGCTTTGA

E E S L *

Fig. 5. DNA sequence and the deduced amino acid sequences of $r \mathrm{fbK}$ and $r \mathrm{fb} M$ of $E$. coli 09 . Possible promoter regions are boxed and the potential Shine-Dalgarno sequences are double underlined.

tative results are shown in Fig. 4(b, c) and all results are summarized in Table 2 . From these results $E$. coli $\mathrm{O} 9 \mathrm{rfb}$ seems to be composed of two regions: a region common to the four $r f b$ clusters (probes 1-3 and 8-9) and a region specific to E. coli $\mathrm{O} 9$ and Klebsiella $\mathrm{O} 3$ which have identical $O$ polysaccharides (probes 4-7). The strainspecific region, which seems to determine the polysaccharide structures, is flanked by two common regions, which may include genes encoding either mannose pathway enzymes or transferases common to the synthesis of these four $\mathrm{O}$ polysaccharides.

\section{Complementation of S. typhimurium rfb}

Well-defined $r f b$ mutants of $S$. typhimurium are available which are deleted in either $r f b K$ or in both $r f b K$ and $r f b M$ (Nikaido et al., 1967) and these strains were used in a complementation study with pNKB26 and its derivatives 
Table 4. Specific activity of enzymes in the mannose pathway

\begin{tabular}{|llrc|}
\hline Strain & Plasmid & \multicolumn{2}{c|}{$\begin{array}{c}\text { Specific activity } \\
\left(\mathbf{m U} \mathbf{~ m g}^{-1}\right)\end{array}$} \\
\cline { 3 - 4 } & & PMM & GMP \\
& & $37 \cdot 6$ & $0 \cdot 9$ \\
\hline HU1190 & - & $175 \cdot 3$ & $13 \cdot 7$ \\
HU1190 & pBHC1-Sc6 & $317 \cdot 1$ & $0 \cdot 0$ \\
HU1190 & pBHC1-rfbK & $32 \cdot 5$ & $23 \cdot 9$ \\
HU1190 & pBHC1- $r f b M$ & & \\
\hline
\end{tabular}

(Table 3). The results indicated that the defects in the genes for polypeptides of 50 and $55 \mathrm{kDa}$ were complemented by $r f b K$ and $r f b M$ of $S$. typhimurium, respectively. Thus, the genes for polypeptides of 50 and $55 \mathrm{kDa}$ correspond to $r f b K$ and $r f b M$ of $S$. typhimurium and hereafter we use $r f b K_{\mathrm{EO} 9}$ and $r f b M_{\mathrm{EO} 9}$ for genes of 50 and $55 \mathrm{kDa}$ polypeptides of $\mathrm{E}$. coli $\mathrm{O} 9$.

\section{DNA sequences of $r \mathrm{fbK}_{\mathrm{EOg}}$ and $r \mathrm{fb} M_{\mathrm{EO} 9}$}

The DNA sequence of a $3.1 \mathrm{~kb}$ fragment including $r f b K_{\mathrm{EO} 9}$ and $r f b M_{\mathrm{EO} 9}$, and the predicted amino acid sequences are shown in Fig. 5. Two open reading frames for $r f b K_{\mathrm{EO} 9}$ and $r f b M_{\mathrm{EO}}$ were found encoding proteins of 460 amino acids (50809 Da) and 471 amino acids $(52789 \mathrm{Da})$, respectively. These were in agreement with the minicell analysis. $r f b K_{\mathrm{EO} 9}$ was located between sequence positions 1755 and 3137 , and $r f b M_{\text {EO9 }}$ between positions 317 and 1732. The Shine-Dalgarno sequences were observed $11 \mathrm{bp}$ in front of the ATG initiation codon of $r f b K_{\mathrm{EO}}$ and $7 \mathrm{bp}$ in front of the initiation codon of $r f b M_{\mathrm{EO} 9}$ (Fig. 5). Sequences homologous to the consensus sequence of $E$. coli $\sigma^{70}$-dependent promoters were found $31 \mathrm{bp}$ upstream of $r f b K_{\mathrm{EO} 9}$ and $79 \mathrm{bp}$ upstream of $r f b M_{\text {Eog. }}$. No inverted repeat sequence was observed downstream of the translational stop codon of $r f b K_{\mathrm{EO}}$ and $r f b M_{\mathrm{EOg}}$. The $\mathrm{G}+\mathrm{C}$ content of both genes is 0.62 , a value higher than that of $E$. coli $(0 \cdot 5)$. Insertion positions of pNKB26:: $\operatorname{Tn} 1000-62$ and -195 are also shown in Fig. 5.

Evidence for an in vivo activity of promoters for $r f b K$ and $r f b M$ was found with plasmid pBHC4 (Fig. 1) and its deletion derivative $\mathrm{pBHC4}-\mathrm{d} 10 \mathrm{~A}$ carrying only $r f b K$. pBHC1-Sc6 (Fig. 3) was used for the detection of enzyme activities of PMM and GMP and found to direct the synthesis of both enzymes in vivo (see below). Plasmids pBHC4 and pBHC4-d10A carry their DNA fragment in the opposite direction to pBHC1-Sc6. Both strains, HU1190(pBHC4)(pXX195) and HU1190(pBHC4 d10A)(pNKB26:: Tn1000-195), synthesized the O9. specific LPS. This indicated that $r f b K$ and $r f b M$ are expressed in E. coli independently of the lac $Z$ promoter. These data suggested that promoters for the expression of the $r f b K$ and $r f b M$ genes are contained in the fragment.

Table 5. Comparison of amino acid identities of deduced sequences from PMM and GMP genes of various bacteria

By using the ODEN program of the National Institute for Genetics, Mishima, Japan, we calculated amino acid identities between PMM and GMP. Numbers show the percentage identities among the deduced amino acid sequences of PMM and GMP.

\begin{tabular}{|c|c|c|c|c|c|c|c|}
\hline \multicolumn{8}{|l|}{ PMM } \\
\hline & $\mathrm{RfbK}_{\mathrm{EO} 7}$ & $\mathrm{RfbK}_{\mathrm{B}}$ & $\mathrm{RfbK}_{\mathrm{Cl}}$ & $\mathrm{RfbK}_{\mathrm{C} 2}$ & CpsG & $\mathrm{Alg} C$ & $\mathrm{Xan} A$ \\
\hline $\mathrm{RfbK}_{\mathrm{EO} 9}$ & 73 & 15 & 75 & 15 & 75 & 30 & 57 \\
\hline $\mathrm{RfbK}_{\mathrm{EO} 7}$ & & 14 & 84 & 13 & 83 & 29 & 55 \\
\hline $\mathrm{RfbK}_{\mathrm{B}}$ & & & 16 & 67 & 17 & 19 & 17 \\
\hline $\mathrm{RfbK}_{\mathrm{C} 1}$ & & & & 14 & 96 & 29 & 60 \\
\hline $\mathrm{RfbK}_{\mathrm{C} 2}$ & & & & & 15 & 17 & 17 \\
\hline $\mathrm{CpsG}^{\mathrm{Cz}}$ & & & & & & 29 & 60 \\
\hline$A \lg C$ & & & & & & & 31 \\
\hline \multicolumn{8}{|l|}{ GMP } \\
\hline & $\mathrm{RfbM}_{\mathrm{EO} 7}$ & $\mathrm{RfbM}_{\mathrm{B}}$ & $\mathrm{RfbM}_{\mathrm{C} 1}$ & $\mathrm{RfbM}_{\mathrm{C} 2}$ & CpsB & $A \lg A$ & XanB \\
\hline $\mathrm{RfbM}_{\mathrm{EO} 9}$ & $49^{\mathrm{cos}}$ & $58^{\circ}$ & $59^{\circ}$ & 57 & 61 & 52 & 57 \\
\hline $\mathrm{RfbM}_{\mathrm{EO} 7}$ & & 47 & 53 & 50 & 52 & 42 & 46 \\
\hline $\mathrm{Rfb}_{\mathrm{B}}$ & & & 57 & 77 & 58 & 49 & 54 \\
\hline $\mathrm{RfbM}_{\mathrm{C} 1}$ & & & & 57 & 70 & 54 & 58 \\
\hline $\mathrm{RfbM}_{\mathrm{C} 2}$ & & & & & 58 & 50 & 55 \\
\hline $\mathrm{CpsB}$ & & & & & & 54 & 61 \\
\hline $\mathrm{A} \lg \mathrm{A}$ & & & & & & & 59 \\
\hline
\end{tabular}




\section{Determination of enzymic activities}

To investigate the specific enzyme activities of PMM and GMP directly, we subcloned a SacI-HindIII fragment of pNKB26 including both $r f b K_{\mathrm{EO} 9}$ and $r f b M_{\mathrm{EO} 9}$ into pBluescript II SK(+) and termed it pBHC1-Sc6 (Fig. 3). Plasmids $\mathrm{pBHC1}-r f b K$ and $\mathrm{pBHC1}-r f b M$, encoding single proteins, were constructed from $\mathrm{pBHC1}-\mathrm{Sc} 6$ by deleting fragments. For the construction of pBHC1-rfbK, the region including the promoter and about one-third of $r f b M_{\text {EO9 }}$ was removed. To construct $\mathrm{pBHC1}-r f b M$, the region including about one-third of the $\mathrm{C}$ terminus of $r f b K_{\mathrm{EO} 9}$ was removed (Fig. 3). Using these plasmids, we measured PMM and GMP activities. As shown in Table 4, pBHC1-Sc6 and $\mathrm{pBHC1}-r f b K$ exhibited PMM activity, whereas pBHC1-rfbM did not. pBHC1-Sc6 and pBHC1$r f b M$ showed GMP activity. The results confirmed that the $50 \mathrm{kDa}$ polypeptide is PMM and the $55 \mathrm{kDa}$ polypeptide is GMP.

\section{Comparison of PMM and GMP of bacterial GDP- mannose pathways}

We compared the nucleotide and deduced amino acid sequences of PMM and GMP genes in $r f b$ clusters of $E$. coli O9 (this study) and O7 (Marolda \& Valvano, 1993), and Salmonella strains of group B (Jiang et al., 1991), C1 (Lee et al., 1992) and C2 (Brown et al., 1992), in the cps cluster of $S$. typhimurium directing the synthesis of the mucoid (M) antigen (Stevenson et al., 1991), in the xan cluster of the xanthan synthetic pathway of Xanthomonas campestris (Köplin et al., 1992) and in the alg cluster of the alginate synthetic pathway of Pseudomonas aeruginosa (Shinabager et al., 1991; Zielinski et al., 1991). The following results were obtained.

(i) Comparison of amino acid identities of PMM and GMP. Table 5 shows the sequence identities between the enzymes. There was pronounced identity between PMM sequences of $\mathrm{RfbK}_{\mathrm{EO} 9}, \mathrm{RfbK}_{\mathrm{EO} 7}, \mathrm{RfbK}_{\mathrm{C} 1}$ and $\mathrm{CpsG}$. $\mathrm{XanA}$ showed relatively high sequence identities with $\mathrm{RfbK}_{\mathrm{EO} 9}$, RfbK $\mathrm{EO}$, $\mathrm{RfbK}_{\mathrm{C} 1}$ and CpsG. Identities between $\mathrm{AlgC}$ and the other PMM sequences were low. As reported previously (Lee et al., 1992), $\mathrm{RfbK}_{\mathrm{C} 1}$ and CpsG were almost identical and $\mathrm{RfbK}_{\mathrm{B}}$ and $\mathrm{RfbK}_{\mathrm{C} 2}$ were similar. However, the degree of sequence identity between GMPs of these bacteria was comparable. No strong divergence was found in GMP sequences.

(ii) Phylogenetic trees of deduced amíno acid sequences from the PMM and GMP genes. The phylogenetic trees of PMM and GMP genes were constructed to show their evolutionary relationships. The trees derived from PMM and GMP genes are shown in Fig. 6. The two phylogenetic trees differed in the evolutionary distances from ancestors. Moreover, they differed from each other in topology. In the case of GMP genes, an ancestor of $\mathrm{RfbM}_{\mathrm{EO} 9}, \mathrm{RfbM}_{\mathrm{EO}}, \mathrm{RfbM}_{\mathrm{C} 1}$ and CpsB diverged from that of $\mathrm{RfbM}_{\mathrm{B}}, \mathrm{RfbM}_{\mathrm{C} 2}, \mathrm{XanB}$ and Alg A first and then diverged into each gene, whereas in the case of the PMM gene, AlgC, XanA, RfbK $\mathrm{Eog}_{\text {, }}$ $\mathrm{RfbK}_{\mathrm{EO} 7}, \mathrm{RfbK}_{\mathrm{C} 1}$ and $\mathrm{Cps}$ are considered to be
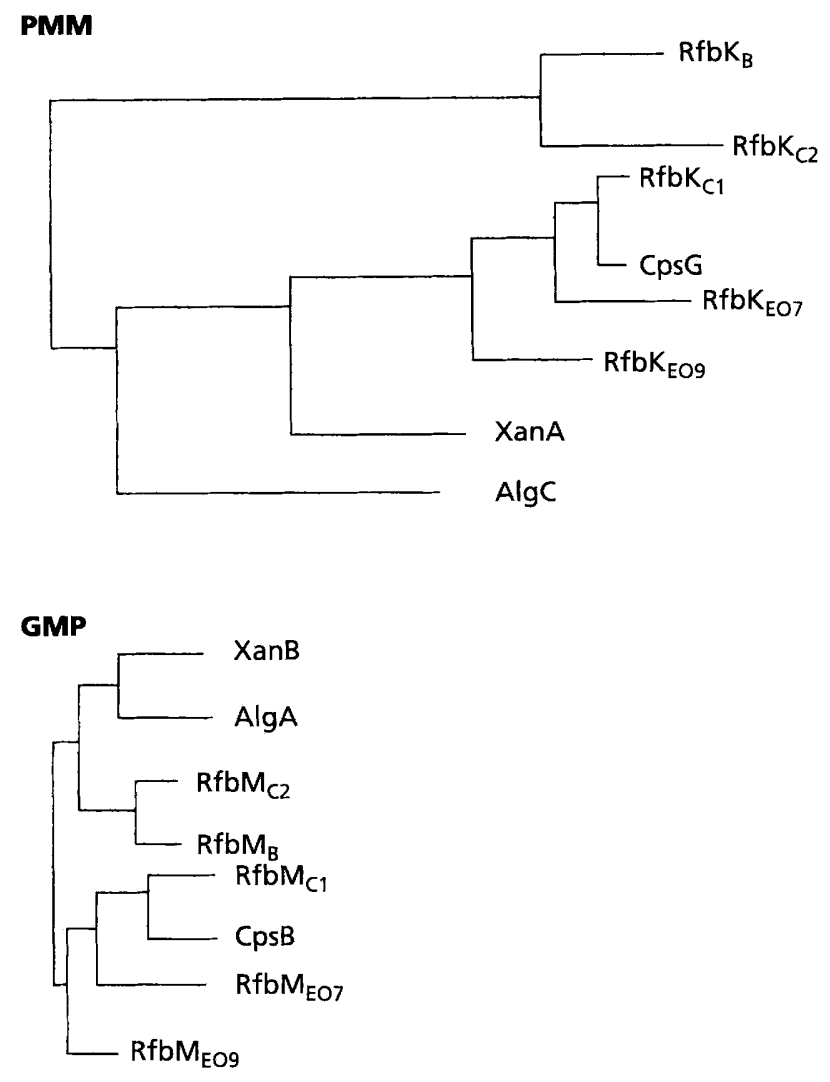

Fig. 6. Phylogenetic trees of deduced amino acid sequences from PMM and GMP genes. Branch length is proportional to evolutionary distance.

monophyletic, although their divergences are ancient. Differences in the evolutionary distance from ancestors and in the topology of phylogenetic trees suggest that genes for $\mathrm{RfbK}$ and $\mathrm{RfbM}$ have evolved independently, though they are both required for the synthesis of GDPmannose in bacteria.

\section{ACKNOWLEDGEMENTS}

We thank S. I. Hull, Texas Medical Center, P. H. Mäkelä, National Public Health Institute, Helsinki, Finland, and G. Schmidt, Forschungsinstitut, Borstel, for providing bacterial strains and phages. The skilled technical assistance of Christiane Heidkämper, Max-Planck-Institut für Immunbiologie, is gratefully acknowledged. This study was supported by a Grant-inAid for Scientific Research (02670179) from the Ministry of Education, Science and Culture of Japan. This work was also supported by an Alexander von Humboldt Stipendium (to N. Kido).

\section{REFERENCES}

Brown, P. K., Romana, L. K. \& Reeves, P. R. (1992). Molecular analysis of the $r f b$ gene cluster of Salmonella serovar muenchen 
(strain M67): the genetic basis of the polymorphism between groups C2 and B. Mol Microbiol 6, 1385-1394.

Clarke, B. R. \& Whitfield, C. (1992). Molecular cloning of the $r f b$ region of Klebsiella pneumoniae serotype $\mathrm{O} 1: \mathrm{K} 20$ : the $r f b$ gene cluster is responsible for synthesis of the D-galactan I O polysaccharide. J Bacteriol 174, 4614-4621.

Guyer, M. S. (1978). The $\gamma \delta$ sequence of $\mathrm{F}$ is an insertion sequence. J Mol Biol 126, 347-365.

Guyer, M. S. (1983). Uses of the transposon $\gamma \delta$ in the analysis of cloned genes. Methods Enzymol 101, 362-369.

Haraguchi, G. E., Zăhringer, U., Jann, B., Jann, K., Hull, R. A. \& Hull, S. I. (1991). Genetic characterization of the $O 4$ polysaccharide gene cluster from Eschericbia coli. Microb Pathog 10, 351-361.

Hitchcock, P. J. \& Brown, T. M. (1983). Morphological heterogeneity among Salmonella lipopolysaccharide chemotypes in silverstained polyacrylamide gel electrophoresis. J Bacteriol 154, 269-277.

Jann, K. \& Jann, B. (1984). Structure and biosynthesis of $O$ antigens. In: Handbook of Endotoxin, vol. 1, pp. 138-186. Edited by E. T. Rietschel. Amsterdam: Elsevier Science Publishers.

Jansson, P.-E., Lönngren, J., Widmalm, G., Leontein, K., Slettengren, K., Svenson, S. B., Wrangsell, G., Dell, A. \& Tiller, P. R. (1985). Structural studies of the $O$-antigen polysaccharides of Klebsiella O5 and Escberichia coli O8, Carbohydr Res 145, 59-66.

Jiang, X.-M., Neal, B., Santiago, F., Lee, S. J., Romana, K. K. \& Reeves, P. R. (1991). Structure and sequence of the $r f b$ (O antigen) gene cluster of Salmonella serovar typhimurium (strain LT2). Mol Microbiol 5, 695-713.

Kessler, A. C., Brown, P. K., Romana, L. K. \& Reeves, P. R. (1991). Molecular cloning and genetic characterization of the $r f b$ region from Yersinia pseudotuberculosis serogroup IIA, which determines the formation of the 3,6-dideoxyhexose abequose. J Gen Microbiol 137, 2689-2695.

Kido, N., Ohta, M., lida, K., Hasegawa, T., Ito, H., Arakawa, Y., Komatsu, T. \& Kato, N. (1989). Partial deletion of the cloned $r f b$ gene of Escherichia coli $\mathrm{O} 9$ results in synthesis of a new $\mathrm{O}$-antigenic lipopolysaccharide. J Bacteriol 171, 3629-3633.

Kido, N., Ohta, M. \& Kato, N. (1990). Detection of lipopolysaccharides by ethidium bromide staining after sodium dodecyl sulfate-polyacrylamide gel electrophoresis. J Bacteriol 172, 11451147.

Komatsu, T., Ohta, M., Kido, N., Arakawa, Y., Ito, H., Mizuno, T. \& Kato, N. (1990). Molecular characterization of an Enterobacter cloacae gene (rom $A$ ) which pleiotropically inhibits the expression of Escherichia coli outer membrane proteins. J Bacteriol 172, 4082-4089.

Köplin, R., Arnold, W., Hotte, B., Simon, R., Wang, G. \& Puhler, A. (1992). Genetics of xanthan production in Xantbomonas campestris: the $x a n A$ and $x a n B$ genes are involved in UDP-glucose and GDPmannose biosynthesis. J Bacteriol 174, 191-199.

Kopmann, H. J. \& Jann, K. (1975). Biosynthesis of the O9 antigen of Escberichia coli: the polysaccharide component of $E$. coli O9: K29-. Eur J Biochem 60, 587-601.

Lee, S. J., Romana, L. K. \& Reeves, P. R. (1992). Sequence and structural analysis of the $r f b$ (O antigen) gene cluster from a group C1 Salmonella enterica strain. J Gen Microbiol 138, 1843-1855.

Makela, P. H. \& Stocker, B. A. D. (1984). Genetics of lipopolysaccharide. In Handbook of Endotoxin, vol. 1, pp. 59-137. Edited by E. T. Rietschel. Amsterdam: Elsevier Science Publishers.

Marolda, C. L. \& Valvano, M. A. (1993). Identification, Expression, and DNA sequence of the GDP-mannose biosynthesis genes encoded by the $\mathrm{O} 7 \mathrm{rfb}$ gene cluster of strain VW187 (Escherichia coli O7:K1). J Bacteriol 175, 148-158.

Marolda, C. L., Welsh, J., Dafoe, L. \& Valvano, M. A. (1990).
Genetic analysis of the O7-polysaccharide biosynthesis region from the Escherichia coli O7: K1 strain VW187. J Bacteriol 172, 3590-3599.

Meagher, R. B., Tait, R. C., Betlach, M. \& Boyer, H. W. (1977). Protein expression in E. coli minicells by recombinant plasmids. Cell 10, 521-536.

Meier-Dieter, U., Barr, K., Starman, R., Hatch, L. \& Rick, P. D. (1992). Nucleotide sequence of the Eschericbia coli rfe gene involved in the synthesis of enterobacterial common antigen.J Biol Chem 267, 746-753.

Mizuta, K., Ohta, M., Mori, M., Hasegawa, T., Nakashima, I. \& Kato, N. (1983). Virulence for mice of Klebsiella strains belonging to the O1 group: relationship to their capsular $(\mathrm{K})$ types. Infect Immun 40, 56-61.

Munch-Petersen, A. (1962). GDPM pyrophosphorylase. Metbods Enzymol 5, 171-174.

Nikaido, H., Levinthal, M., Nikaido, K. \& Nakane, K. (1967). Extended deletions in the histidine-rough-B region of the Salmonella chromosome. Proc Natl Acad Sci USA 57, 1825-1832.

Rick, P. D. (1987). Lipopolysaccharide biosynthesis. In Escbericbia coli and Salmonella typhimurium, pp. 648-662. Edited by F. C. Neidhardt. Washington, DC: American Society for Microbiology. Sá-Correia, l., Darzins, A., Wang, S.-K., Berry, A. \& Chakrabarty, A. M. (1987). Alginate biosynthetic enzymes in mucoid and nonmucoid Pseudomonas aeruginosa: overproduction of phosphomannose isomerase, phosphomannomutase, and GDP-mannose pyrophosphorylase by overexpression of the phosphomannose isomerase (pmi) gene. J Bacteriol 169, 3224-3231.

Saeki, A., Kido, N., Sugiyama, T., Ohta, M., Iwashita, T., Uchiya, K. \& Kato, N. (1993). Isolation of $r f b$ gene clusters directing the synthesis of $\mathrm{O}$ polysaccharides consisting of mannose homopolymers and serological analysis of lipopolysaccharides. Microbiol Immunol 37, 601-606.

Sambrook, J., Fritsch, E. F. \& Maniatis, T. (1989). Molecular Cloning: a Laboratory Manual, 2nd edn. Cold Spring Harbor, NY: Cold Spring Harbor Laboratory.

Sancar, A., Wharton, R. P., Seltzer, S., Kacinski, B. M., Clarke, N. D. \& Rupp, W. D. (1981). Identification of the uvr $A$ gene product. $J$ Mol Biol 148, 45-62.

Sanger, F., Nicklen, S. \& Coulson, A. R. (1977). DNA sequencing with chain-terminating inhibitors. Proc Natl Acad Sci USA 74, 5463-5467.

Sasakawa, C., Kawata, K., Sakai, T., Murayama, S. Y., Makino, S. \& Yoshikawa, M. (1986). Molecular alteration of the 140megadalton plasmid associated with loss of virulence and congo red-binding activity in Shigella flexneri. Infect Immun 51, 470-475.

Shinabarger, D., Berry, A., May, T. B., Rothmel, R., Fialho, A. \& Chakrabarty, A. M. (1991). Purification and characterization of phosphomannose isomerase-guanosine diphospho-D-mannose pyrophosphorylase. J Biol Chem 266, 2080-2088.

Silhavy, T. J., Berman, M. L. \& Enquist, L. W. (1984). Experiments with Gene Fusions. Cold Spring Harbor, NY: Cold Spring Harbor Laboratory.

Stevenson, G., Lee, S. J., Romana, L. K. \& Reeves, P. R. (1991). The cps gene cluster of Salmonella strain LT2 includes a second mannose pathway: sequence of two genes and relationship to genes in the $r f b$ gene cluster. Mol \& Gen Genet 227, 173-180.

Sugiyama, T., Kido, N., Arakawa, Y., Mori, M., Naito, S. \& Kato, N. (1990). Rapid small-scale preparation method of cell surface polysaccharides. Microbiol Immunol 34, 635-641.

Tsai, C. M. \& Frasch, C. E. (1982). A sensitive silver stain for detecting lipopolysaccharides in polyacrylamide gels. Anal Biochem 119, 115-119. 
Valvano, M. A. \& Crosa, J. H. (1989). Molecular cloning and expression in Escherichia coli K-12 of chromosomal genes determining the $\mathrm{O} 7$ lipopolysaccharide antigen of a human invasive strain of E. coli O7: K1. Infect Immun 57, 937-943.

Zielinski, N. A., Chakrabarty, A. M. \& Berry, A. (1991). Character- ization and regulation of the Pseudomonas aeruginosa alg $C$ gene encoding phosphomannomutase. J Biol Chem 266, 9754-9763.

Received 27 May 1993; revised 9 August 1993; accepted 16 August 1993. 